\title{
The Cultivation of High School Students' Interest in English Reading
}

Fan Peini

Shijiazhuang Foreign Language School

Abstract: English learning involves listening, speaking, reading and writing, and each aspect of them can not be ignored. What matters in improving reading ability is to cultivate English reading interest of high school students at first. Interest is the best teacher, and also an indirect way to improve high school students' ability of English reading. As a high school student, I put forward some views and opinions on the cultivation of high school students' interest in English reading which are based on my own learning experience. Hoping to help the peers in English reading.

Keywords: high school students, English, reading interest, cultivation

Published Date: January 2018

Published Online: $31^{\text {st }}$ January 2018

\section{The current situation of high school students' English reading}

As for high school students, one of the most effective methods to improve English grades is to improve their reading competence. Because in an English test paper, the scores of cloze and reading comprehension account for almost half of the total. But after communicating with many students, I realize that some of them still do not pay attention to improve their reading ability, and even hold the view that their English can be improved naturally if they accumulate enough words and have a good command of grammar. Whether reading or not is not important. How many pages you have read is not important. In fact, these opinions are the reflections of lacking interest in English reading in high school.

\section{A. Neglecting the accumulation of new words or paying much attention to it in dealing with reading}

In school, many students believe that the most effective way to improve their ability of English reading is to enlarge their vocabulary. So, they try to keep not only textbook vocabulary but also extracurricular words in mind, and some of them even begin to remember words in the Oxford Dictionary from the 1st page. With long-term perseverance and accumulation, their amount of words has been improved markedly, but with little improvement in reading skills and English grades. While some students hold the opposite opinions, they think the relationship between reading ability and the amount of words is not so close. Such students give more priority to in-class reading, such as textbooks, and extracurricular reading than remembering new words. As long as the text is not beyond their capabilities, they will read it. But the texts they are going to read may be beyond their ability and the materials of reading and reading comprehension in exam are various, so students also need to keep enlarging their vocabulary, just as a saying goes: "One is never too old to learn." Therefore, high school students should correctly understand the close relationship between vocabulary and English reading, so as both of them can complement each other and promote together.

\section{B. Lacking mastery of the content as well as knowledge of the article and cultural background}

Cultural background refers to knowledge people have acquired before reading, which can be a common sense or a long-term accumulation of knowledge or experience. Cultural background includes cultural customs, folk customs, history, 
geography, Western mythology, The Bible, economics, politics of current affairs, etc. Almost all English reading comprehension contains such knowledge. Better understanding of reading comprehension requires an effective interaction between cultural background and the passage, because background knowledge plays a crucial role in understanding the original text. However, in English reading comprehension, the author does not tend to show all information completely or accurately, which certainly will hinder students in understanding reading comprehension in some degree. While students can have a better understanding of the whole idea of the text if they take advantage of their knowledge acquired in previous study and experience. Generally, we can have an in-depth understanding of the author' $s$ thought at that time from his or her background and other cultural differences, such as, his or her country and religion

\section{How to develop the interest in English reading according to students' own conditions}

Interest is the best teacher, without which, nothing can be achieved. In terms of the interest in English reading and reading ability, the cultivation of reading interest is the premise and foundation of improving reading ability, while improving reading ability is the aim of developing reading interest. Therefore, only by improving reading ability can high school students gain confidence in English learning and get good grades.

On the one hand, as high school students, when learning how to read English, we need teachers to guide us and stimulate our reading interest. Teachers should clarify the relationship between vocabulary and reading skills, help us find a suitable way for developing our interest in reading English. They also need to help us build up self-confidence, and encourage us to read more and speak more. Meanwhile, due to students' different personalities, targeted cultivation of the interest can be conducted. Teachers can choose the content and style of the reading material according to students' tastes. For example, some students are interested in narration, they can be given some touching English stories to read. In short, reading material should be simple in some degree and easy to understand, so that students can have confidence in English reading. 1. Teachers are supposed to regularly hold English reading contests, recitation contests, English host competitions and other programs to arouse students' interest in English reading. Competing in contests is a good way to stimulate students' desire for learning. Through this way, students can not only enrich their extra-curricular life, but also read more articles. 2. Teachers should bring into full play their role in guiding to arouse students' enthusiasm of English reading. National English Curriculum Standards for Common Senior High School explicitly stipulates that teachers should shift their role accordingly in teaching. They should be promoters, instructors, organizers, helpers, participants and collaborators in students' learning process, not only knowledge imparters. They need to consciously guide students to develop their ability to learn independently, so that students' subjective status can be enhanced. Therefore, teachers should actively create a relaxing and enjoyable teaching environment in class, and properly use effective teaching methods to give full play to their leading role, so that students' interest in English reading can be mobilized, no matter in class or out of class.

On the other hand, due to diverse learning characteristics, as students, we should find our own way to study English reading according to our own reading interest. First of all, we need to enlarge our vocabulary to clear the obstacles for reading. Learning English is just like putting up a building. As its bricks, vocabulary is the cornerstone and the foundation. Therefore, to improve reading ability requires us to enlarge our vocabulary, so that the obstacles we encountered in reading can be cleared. In our daily study, we need to pay attention to the accumulation of words. In the process of reading, once coming across new words, we can take them down and look up their meanings to deepen our impression of them. Sometimes in order to save time, when teachers assign reading tasks, we can write down the new words in the reading material before reading. In our daily study, some key words need to 
be memorized repeatedly. Gradually our vocabulary will be enlarged, which does benefit in grasping the meaning of the reading material, leading to more interest in English reading. Once the problem of vocabulary is solved, we can pick up what we want to read to enjoy the pleasure of reading. Second, we can regularly watch some English movies we are interested in, and learn to sing English songs. Practice makes perfect. Step by step, we will understand English movies and appreciate the beauty in English songs. Third, we can make pen friends with foreigners through the Internet, learn from each other, and exchange reading journals. You will find that reading really has so much fun.

\section{Conclusion}

In a word, reading comprehension is an integrated process, and improving reading ability will take a long time. For English learners, the more background knowledge they have, the faster they understand the article. The accuracy rate in exam will also be increased. Therefore, during high school years, we should try our best to master the language, and strive to widen the scope of our knowledge at the same time.

\section{References}

[1] Wang Ying, Fu Yuan. On How to Stimulate the Interest of Middle School Student in English Studying. Foreign Languages Teaching and Research: Edition for Teacher, 2009(11)

[2] Xu Wenlong. What affects Chinese students' reading competence? [J]. Modern Foreign Language, 1998

[3] Chen Yongfang, Gong Xiaoling, Chen Xiaoyan, Sun Zhicheng. Strategy Training in the Teaching of English Reading: Experience and Promotion [M]. Zhejiang: Zhejiang University Press. 2014 